\title{
PENGARUH GAYA KEPEMIMPINAN DAN MOTIVASI TERHADAP KINERJA GURU DENGAN KEPUASAN KERJA SEBAGAI VARIABEL MODERASI
}

\author{
Yuniz Majidah ${ }^{1^{*}}$, Tin Agustina Karnawati², Ike Kusdyah Rachmawati ${ }^{3}$ \\ 1,2,3 Institut Teknologi dan Bisnis Asia Malang, Indonesia
}

INFO ARTIKEL

DOI: $10.32812 /$ jibeka.v14i2.173

ISSN-P: 0126-1258

ISSN-E: 2620-875X

Keywords: Situational leadership style, job motivation, job satisfaction, teacher's performance

\section{ABSTRACT}

The principal should have caring to improving the quality of education. Such caring should be demonstrated with the will and ability to develop themselves optimally, so the teachers and education personnel can improve their performance. The teacher's performance is influenced by several factors are situational leadership style, work motivation and job satisfaction. The purpose of this research is to know and analyse the influence of situational leadership style, job motivation, and job satisfaction on the teacher's performance, the influence of situasional leadership style and job motivation to the performance of teachers moderated in job satisfaction. The population of this research is the teachers of accredited pre-primary school in Singaraja Cit Bali. The data collection techniques in this research are the observation and distribution of questionnaires. This research uses data analysis methods using SmartPLS software. The results showed that the situational leadership style, job motivation, and job satisfaction affects the teacher's performance of the accredited pre-primary schools in Singaraja City Bali, and the situational leadership style, and job motivation have no effect the teacher's performance who are moderated job satisfaction at the preprimary school accredited in Singaraja City Bali.

\section{ABSTRAK}

Kepala sekolah harus memiliki perhatian yang cukup tinggi terhadap peningkatan kualitas pendidikan.Perhatian tersebut harus ditunjukkan dengan kemauan dan kemampuan untuk mengembangkan diri secara optimal, sehingga bawahannya yaitu guru dan tenaga kependidikannya dapat meningkatkan kinerjanya. Kinerja guru dipengaruhi oleh beberapa faktor yaitu gaya kepemimpinan situasional, motivasi kerja dan kepuasan kerja. Tujuan Penelitian ini adalah untuk mengetahui dan menganalisis pengaruh gaya kepemimpinan situasional, motivasi kerja, dan kepuasan kerja terhadap kinerja guru, pengaruh gaya kepemimpinan situasional dan motivasi kerja terhadap kinerja guru yang dimoderasi oleh kepuasan kerja. Populasi penelitian ini adalah seluruh guru di Taman Kanak-Kanak Swasta yang terakreditasi di Kota Singaraja Bali. Teknik pengumpulan data pada penelitian ini adalah observasi dan penyebaran angket (kuesioner). Penelitian ini menggunakan metode analisis data dengan menggunakan software SmartPLS. Hasil penelitian menunjukkan bahwa gaya kepemimpinan situasional, motivasi kerja, dan kepuasan kerja berpengaruh terhadap kinerja guru pada Taman Kanak-Kanak yang terakreditasi di Kota Singaraja Bali, gaya kepemimpinan situasional dan motivasi kerja tidak berpengaruh terhadap kinerja guru yang dimoderasi kepuasan kerja pada Taman Kanak-Kanak yang terakreditasi di Kota Singaraja Bali. 


\section{Pendahuluan}

Pendidikan merupakan proses pembelajaran kepada peserta didik dalam memiliki pemahaman terhadap konsep dan berfikir lebih kritis. Proses pembelajaran dilakukan dengan tujuan meningkatkan potensi peserta didik, sehingga mereka memiliki kekuatan spiritual yang baik, pengendalian diri, kepribadian, kecerdasan, akhlak mulia dan juga keterampilan yang diperlukan oleh diri sendiri, bangsa dan negara.

Seperti yang telah dituangkan dalam UU Sisdiknas No. 20/2003 pasal 1 angka 14 : Pendidikan anak usia dini adalah pembinaan untuk anak sejak lahir sampai usia enam tahun dilakukan dengan mendidik anak untuk pertumbuhan dan mengembangkan jasmani dan rohani agar anak siap dalam memasuki pendidikan dasar. Taman kanak-kanak (TK) merupakan pendidikan prasekolah dalam program pendidikan dini bagi anak usia dini (usia 4 tahun sampai 6 tahun). Pendidikan TK untuk melanjutkan pendidikan dasar serta memperkuat peserta didik menjadi generasi yang memiliki kreatifitas, mental yang kuat, serta dapat memiliki kemandirian lebih dalam menghadapi pendidikan selanjutnya, yaitu pendidikan sekolah dasar.

Setiap jenjang pendidikan memiliki kepala sekolah sebagai pemimpin kebijakan di sekolah. Kepala sekolah harus mengetahui perannya secara maksimal dan sebagai pemimpin sekolah dengan bijak serta mampu mengarahkan untuk pencapaian tujuan secara maksimal dengan meningkatkan kualitas dan mutu pendidikan di sekolah untuk mempengaruhi pada kualitas lulusan anak didik sehingga dapat membanggakan dan membuat masa depan yang cerah. Rachmawati (2008:14-15) mengungkapkan manajemen sumber daya manusia adalah suatu tindakan untuk membentuk satuan kerja yang efektif dalam suatu organisasi. Sehingga para guru dapat mengelola dan melaksanakan tugasnya untuk meningkatkan kinerja guru. Hal tersebut menunjukkan Kepala Sekolah di lingkungan pendidikan nasional diberikan diklat dengan harapan agar sumber daya manusia (SDM) meningkat dan mampu memimpin sekolah. Tanggung jawab dan tugas kepala sekolah sangat berat dan harus dilaksanakan secara optimal, kepala sekolah harus menerapkan gaya kepemimpinan situasional yang tepat. Namun, tidak berhenti pada gaya kepemimpinan situasional yang tepat, tetapi gaya kepemimpinan situasional yang diterapkan harus efektif. Kepemimpinan yang efektif terlihat pada interaksi antara situasi dan perilaku pemimpin (Gibson et.al dalam Wahyudi, 2015).

Menurut Isbandi (dalam Uno Hamzah B, 2010:3) motivasi tidak dapat diamati secara langsung,tetapi dapat dilihat dalam tingkah lakunya, berupa dorongan, atau pembangkit tenaga munculnya suatu tingkah laku. Motivasi merupakan istilah umum yang mengacu pada faktor-faktor yang ada didalam diri individu atau organisasi untuk membangkitkan dan mempertahankan perilaku yang diarahkan dalam memenuhi jumlah kebutuhan atau dorongan untuk pencapaian suatu tujuan. Seorang guru bila memiliki motivasi kerja tinggi maka akan menghasilkan kinerja yang tinggi, demikian pula sebaliknya. Dari pengamatan langsung ke beberapa sekolah dengan melalui metode wawancara, peneliti menemukan bahwa tingkat motivasi kerja guru yang rendah, dikarenakan kurangnya penghargaan terhadap prestasi guru seperti guru yang mendapatkan juara dalam membuat karya ilmiah dan guru yang berhasil membimbing anak didiknya mengikuti lomba, sehingga berdampak terhadap motivasi kerja dan pengembangan diri dalam mengajar yang semakin menurun, ini tidak sesuai dengan harapan sekolah. Dalam hal ini guru sebagai faktor terdepan pendidikan tentu harus bekerja keras untuk menghasilkan dan membawa anak didik kepada gerbang kesuksesan dan keberhasilan.

Kepuasan kerja adalah hal penting yang dimiliki individu dalam bekerja. Setiap guru memiliki karakteristik yang berbeda, maka tingkat kepuasan kerjanya pun berbeda juga. Tinggi rendahnya kepuasan kerja dapat memberikan dampak yang tidak sama. Hal ini berdampak pada mental individu yang ber-sangkutan sebagaimana Roe dan Byars (dalam Donni Juni Priansa 2014: 291) mengatakan bahwa kepuasan kerja yang tinggi dapat mewujudkan tujuan organisasi secara efektif. Tetapi tingkat kepuasan kerja yang rendah dapat menghancurkan organisasi, secara cepat maupun perlahan.Kepuasan kerja 
merupakan perasaan puas,senang, dan nyaman dalam menyelesaikan pekerjaan, sehingga guru termotivasi dalam melaksanakan tugasnya dan tercipta lingkungan belajar yang produktif dan menyenangkan.

Kinerja guru dalam penelitian ini yaitu tentang hasil kerja guru dalam mengelola dan menyelesaikan tugas pendidikan dalam pengajaran, berdasarkan tanggung jawab yang profesional sesuai dengan aturan masing-masing sekolah. Kinerja guru sangat erat dengan manajemen pendidikan yang memberikan kewenangan kepada Kepala Sekolah dalam melaksanakan perencanaan, pengorganisasian, pengawasan dan pengendalian pendidikan di Taman Kanak-Kanak. Kepala Sekolah harus memiliki perhatian yang cukup tinggi terhadap peningkatan kualitas pendidikan.Perhatian yang diberikan sesuai dengan kemauan dan kemampuan untuk mengembangkan diri secara optimal, sehingga para guru dan tenaga kependidikannya dapat meningkatkan kinerjanya. (Mulyasa, 2005: 116).

Penelitian terdahulu yang dilakukan oleh Ahmad Husaini (2017) menemukan hasil bahwa Kepemimpinan Situasional tidak berpengaruh secara signifikan terhadap kinerja guru MTs Negeri Di Kecamatan Gambut Kabupaten Banjar.Selain itu, H. Muhammad Basir (2014) memperoleh kesimpulan penelitian bahwa Motivasi berprestasi berpengaruh signifikan terhadap kinerja guru SMP Negeri Kabupaten Wajo, Rika Dewi Saputri, Suprayitno, Sutarno (2016) memperoleh hasil bahwa Kepuasan Kerja tidak berpengaruh signifikan terhadap kinerja guru yang berstatus PNS di SMP Negeri 1 Jumapolo. Temuan ini turut dikuatkan oleh Arifzan (2015), bahwa gaya kepemimpinan tidak berpengaruh signifikan terhadap kinerja pegawai yang dimoderasi oleh kepuasan kerja pada pegawai Kantor Kesatuan Bangsa Politik dan Perlindungan Masyarakat. Secara keseluruhan, hasil penelitian terdahulu menunjukkan temuan empiris yang seragam. Untuk itu, perlu dilakukan penelitian yang lebih mendalam untuk mengkaji gaya kepemimpinan situasional dan motivasi kerja terhadap kinerja guru dengan kepuasan kerja sebagai variabel moderasi. Penelitian ini bertujuan untuk mengetahui pengaruh dari gaya kepemimpinan situasional, motivasi kerja terhadap kinerja guru dengan kepuasan kerja sebagai variabel moderasi pada taman kanak-kanak yang terakreditasi di Kota Singaraja Bali.

\section{Metode Penelitian}

Penelitian ini menggunakan metode kuantitatif dengan Populasi penelitian seluruh guru Taman Kanak-Kanak Swasta Di Kota Singaraja sebanyak 33 Sekolah Taman KanakKanak di Kota Singaraja. Obyek dalam penelitian ini di 33 TK Swasta tersebut dikarenakan 33 TK Swasta ini sudah terakreditasi. Sampel merupakan bagian dari elemen-elemen populasi (Indriantoro dan Supomo,2012). Teknik Non Probability Sampling yang digunakan yaitu dengan Sampling Jenuh (sensus) metode pengambilan sampel bila semua anggota populasi dijadikan sebagai sampel.Dalam penelitian ini sampel yang akan diambil adalah seluruh guru dari 33 TK Swasta yang ada di Kota Singaraja yaitu 146 responden yang terdiri dari guru PNS dan Non PNS. Sebelum dilakukan pengujian hipotesis, dilakukan analisa outer model dan inner model. Adapun analisis persamaan struktural (SEM) digunakan untuk membuktikan hipotesis penelitian sebagai berikut $\mathrm{H} 1$ : $\mathrm{Di}$ duga gaya kepemimpinan situasional berpengaruh terhadap kinerja guru; H2: Di duga motivasi kerja berpengaruh terhadap kinerja guru; H3: Diduga kepuasan kerja berpengaruh terhadap kinerja guru; $\mathrm{H} 4$ : Di duga gaya kepemimpinan situasional berpengaruh terhadap kinerja guru yang dimoderasi kepuasan kerja; H5: Diduga motivasi kerja berpengaruh terhadap kinerja guru yang dimoderasi kepuasan kerja, sehingga, kerangka konseptual dalam penelitian ini dapat digambarkan seperti pada Gambar 1. 
Gambar 1. Kerangka konsep penelitian

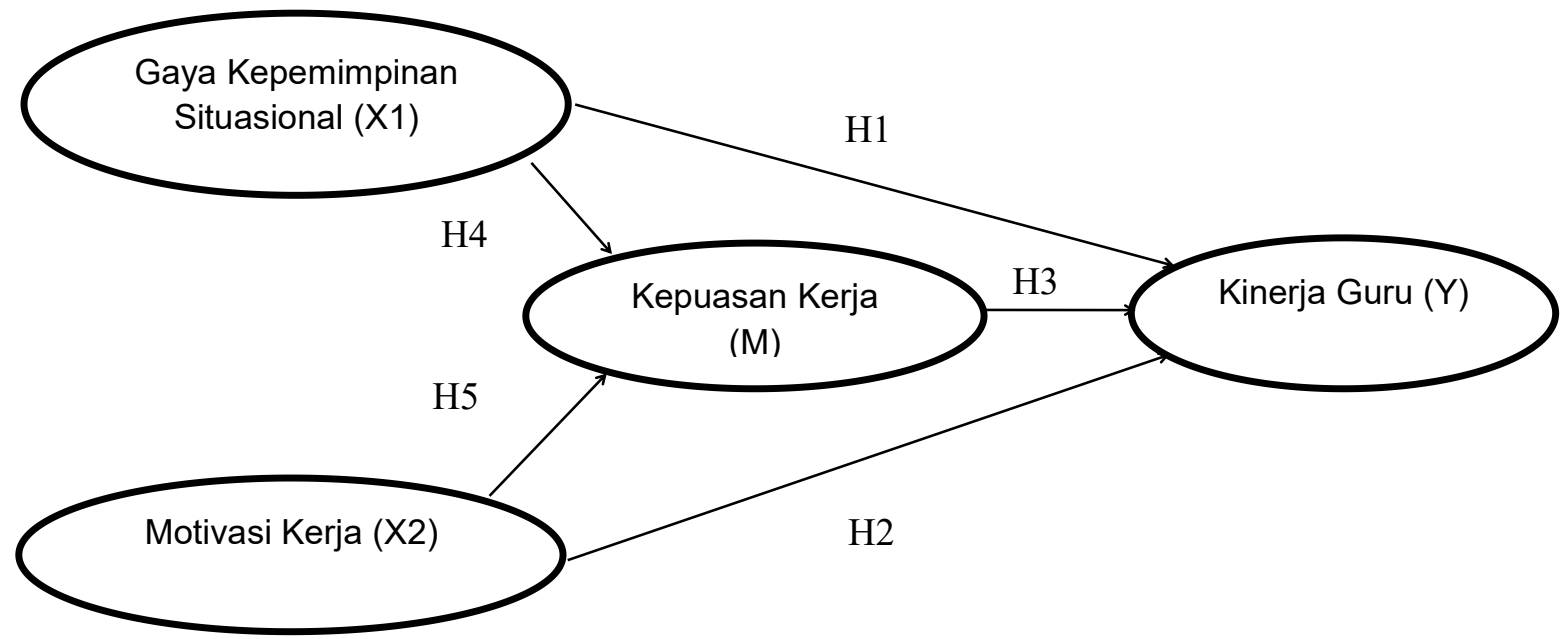

Sumber: Peneliti, 2020

\section{Hasil Penelitian dan Pembahasan}

Tabel 1. Path Coefficients

\begin{tabular}{|l|r|r|r|r|r|r|}
\hline & $\begin{array}{c}\text { Original } \\
\text { Sampel } \\
(\mathrm{O})\end{array}$ & $\begin{array}{c}\text { Sample } \\
\text { Mean (M) }\end{array}$ & $\begin{array}{c}\text { Standard } \\
\text { Deviation } \\
\text { (STDEV) }\end{array}$ & $\begin{array}{c}\text { T Statistics } \\
(\mid \mathrm{O} / \mathrm{STDEV})\end{array}$ & P Values & Ket \\
\hline $\begin{array}{l}\text { Gaya kepemimpinan situasional } \\
\text { (X1) -> Kinerja Guru (Y) }\end{array}$ & $-0,127$ & $-0,119$ & 0,054 & 2,328 & 0,020 & Signifikan \\
\hline $\begin{array}{l}\text { Motivasi Kerja (X2) -> Kinerja } \\
\text { Guru (Y) }\end{array}$ & 0,394 & 0,392 & 0,068 & 5,842 & 0,000 & Signifikan \\
\hline $\begin{array}{l}\text { Kepuasan Kerja (M) -> Kinerja } \\
\text { Guru (Y) }\end{array}$ & 0,621 & 0,615 & 0,077 & 8,097 & 0,000 & Signifikan \\
\hline $\begin{array}{l}\text { Moderating Effect 1 (X1-M) -> } \\
\text { Kinerja Guru (Y) }\end{array}$ & $-0,038$ & $-0,043$ & 0,059 & 0,649 & 0,517 & $\begin{array}{c}\text { Tidak } \\
\text { Signifikan }\end{array}$ \\
\hline $\begin{array}{l}\text { Moderating Effect 2 (X2-M)-> } \\
\text { Kinerja Guru (Y) }\end{array}$ & 0,057 & 0,064 & 0,069 & 0,831 & 0,406 & $\begin{array}{c}\text { Tidak } \\
\text { Signifikan }\end{array}$ \\
\hline
\end{tabular}

Sumber: Peneliti, 2020

Pengujian Hipotesis H1, Variabel X1 (Gaya kepemimpinan situasional) terhadap Variabel Y (Kinerja Guru). Berdasarkan hasil bootstrapping pada Tabel 5.11 di atas, nilai original sample estimate menunjukan nilai negatif sebesar $-0,127$ yang menunjukan bahwa arah hubungan variabel gaya kepemimpinan situasional (X1) terhadap variabel Kinerja Guru (Y) adalah negatif. T-statistics untuk variabel gaya kepemimpinan situasional (X1) terhadap variabel Kinerja Guru (Y) sebesar 2,328 > t-tabel $(1,96)$. Dengan demikian $\mathrm{H} 1$ pada penelitian diterima. Hal ini menunjukkan bahwa $\mathrm{H} 1$ pada variabel laten gaya kepemimpinan situasional (X1) dengan indikator-indikatornya berpengaruh secara signifikan terhadap variabel laten Kinerja Guru $(Y)$.

Pengujian Hipotesis H2, Variabel X2 (Motivasi Kerja) terhadap Variabel Y (Kinerja Guru). Pada H2 nilai original sample estimate menunjukan nilai positif sebesar 0,394 yang menunjukan bahwa arah hubungan variabel Motivasi Kerja (X2) terhadap variabel Kinerja Guru $(Y)$ adalah positif. T-statistics untuk variabel Motivasi Kerja (X2) terhadap variabel Kinerja Guru (Y) sebesar 5,842 > t-tabel $(1,96)$. Dengan demikian $\mathrm{H} 2$ pada penelitian diterima, sehingga variabel laten Motivasi Kerja (X2) dengan indikator- indikatornya berpengaruh terhadap variabel laten Kinerja Guru $(Y)$ secara signifikan.

Pengujian H3, Hipotesis Variabel M (Kepuasan Kerja) terhadap Variabel Y (Kinerja Guru). Pada $\mathrm{H} 3$ nilai original sample estimate menunjukan nilai positif sebesar 0,621 yang menunjukan bahwa arah hubungan variabel Kepuasan Kerja (M) terhadap variabel Kinerja 
Guru (Y) adalah positif. T-statistics untuk variabel Kepuasan Kerja (M) terhadap variabel Kinerja Guru (Y) sebesar 8,097 > t-tabel $(1,96)$. Dengan demikian H3 pada penelitian diterima, sehingga variabel laten Kepuasan Kerja $(\mathrm{M})$ dengan indikator- indikatornya berpengaruh terhadap variabel laten Kinerja Guru $(Y)$ secara signifikan.

Pengujian H4, Hipotesis Variabel X1 (gaya kepemimpinan situasional) terhadap Variabel Y (Kinerja Guru) yang dimoderasi oleh Variabel (M) Kepuasan Kerja. Pada H4 nilai original sample estimate menunjukan nilai negatif sebesar -0,038 yang menunjukan bahwa arah hubungan variabel gaya kepemimpinan situasional (X1) terhadap variabel Kinerja Guru (Y) yang dimoderasi oleh variabel Kepuasan Kerja (M) adalah negatif. T-statistics untuk variabel gaya kepemimpinan situasional (X1) terhadap variabel Kinerja Guru (Y) yang dimoderasi oleh variabel Kepuasan Kerja (M) sebesar 0,649 < t-tabel $(1,96)$. Dengan demikian $\mathrm{H} 4$ pada penelitian ditolak, sehingga variabel laten gaya kepemimpinan situasional (X1) yang dimoderasi oleh variabel Kepuasan Kerja (M) dengan indikator- indikatornya tidak berpengaruh terhadap variabel laten Kinerja Guru $(Y)$ secara tidak signifikan.

Pengujian H5, Hipotesis Variabel X2 (Motivasi Kerja) terhadap Variabel Y (Kinerja Guru) yang dimoderasi oleh Variabel (M) Kepuasan Kerja. Pada H5 nilai original sample estimate menunjukan nilai positif sebesar 0,057 yang menunjukan bahwa arah hubungan variabel Motivasi Kerja (X2) terhadap variabel Kinerja Guru (Y) yang dimoderasi oleh variabel Kepuasan Kerja (M) adalah positif.T-statistics untuk variabel Motivasi Kerja (X2) terhadap variabel Kinerja Guru ( $\mathrm{Y}$ ) yang dimoderasi oleh variabel Kepuasan Kerja (M) sebesar 0,831 $<$ t-tabel $(1,96)$. Dengan demikian H5 pada penelitian ditolak, sehingga variabel laten Motivasi Kerja (X2) yang dimoderasi oleh variabel Kepuasan Kerja (M) dengan indikatorindikatornya tidak berpengaruh terhadap variabel laten Kinerja Guru (Y) secara tidak signifikan.

Pengaruh Gaya kepemimpinan situasional terhadap Kinerja Guru. Hasil kalkulasi dengan menggunakan software SmartPLS 3.0, dihasilkan bahwa Gaya kepemimpinan situasional berpengaruh secara signifikan yang arah hubungannya negatif atau berlawanan arah terhadap kinerja guru. Gaya gaya kepemimpinan situasional yang dimaksudkan ini adalah Gaya Kepemimpinan Situasinal yang meliputi mendikte (telling), menjual (selling), partisipasi (Participating), delegasi (delegating). Seorang pemimpin harus memahami dan mampu menempatkan gaya kepemimpinan situasional. Pada taman kanak-kanak di Kota Singaraja Bali, dengan menerapkan gaya gaya kepemimpinan situasional Kepala sekolah selaku pemimpin dan guru selaku bawahannya akan saling mendukung serta memahami. Dengan demikian, kinerja guru telah tercapai, terutama dalam hal gaya kepemimpinan situasional terhadap pimpinannya, dimana kepala sekolah harus mengetahui setiap keadaan guru. Hasil dari penelitian ini terbukti bahwa taman kanak-kanak di Kota Singaraja membutuhkan pemimpin yang saling mendukung serta memahami setiap guru. Semakin tinggi tingkat gaya kepemimpinan situasional semakin rendah tingkat kinerja guru. Penelitian ini sesuai dengan hasil penelitian oleh Dini Dwiyani, Alit Sarino (2018), bahwa gaya kepemimpinan situasional Kepala Sekolah berpengaruh terhadap kinerja guru.

Pengaruh Motivasi kerja terhadap Kinerja Guru. Dalam penelitian ini membuktikan bahwa motivasi kerja berpengaruh signifikan terhadap kinerja guru. Motivasi kerja pada penelitian ini terbukti bahwa para guru semakin termotivasi dalam melaksanakan kegiatan belajar mengajar dan mendapatkan apresiasi atas prestasi yang dicapai selama mengajar karena semakin guru termotivasi maka kinerja guru akan meningkat dengan baik. Dalam penelitian ini, bahwa pada taman kanak-kanak di Kota Singaraja Bali kinerja guru ditentukan oleh motivasi kerja pada setiap guru. Penelitian ini sesuai dengan hasil penelitian oleh Ahmad Husaini (2017),Dini Dwiyani, Alit Sarino (2018), Suryani Dewi Pratiwi (2013), Arifzan (2015), Luis Aparicio Guterres, Wayan Gede Supartha (2016) bahwa motivasi kerja berpengaruh terhadap kinerja guru.

Pengaruh Kepuasan Kerja terhadap Kinerja Guru. Dalam penelitian ini membuktikan bahwa kepuasan kerja berpengaruh signifikan terhadap kinerja guru. Kepuasan kerja pada penelitian ini terbukti bahwa para guru semakin memiliki perasan puas, senang dan nyaman ddalam melaksanakan kegiatan belajar mengajar dan mendapatkan apresiasi atas prestasi 
yang dicapai selama mengajar karena semakin guru merasa puas maka kinerja guru akan meningkat dengan baik. Dalam penelitian ini, bahwa pada taman kanak-kanak di Kota Singaraja Bali kinerja guru ditentukan oleh kepuasan kerja pada setiap guru. Penelitian ini sesuai dengan hasil penelitian oleh H Muhammad Basir (2014), Arifzan (2015) bahwa kepuasan kerja berpengaruh terhadap kinerja guru. Penelitian ini berbanding terbalik dari penelitian Rika Dewi Saputri, Suprayitno,Sutarno (2016) yang menunjukkan tidak berpengaruh signifikan kepuasan kerja terhadap kinerja guru.

Pengaruh gaya kepemimpinan situasional terhadap Kinerja Guru di Moderasi Kepuasan Kerja. Hasil dari penelitian ini adalah kepuasan kerja tidak memoderasi pengaruh gaya kepemimpinan situasional terhadap kinerja guru. Hal ini menunjukkan bahwa bagaimanapun gaya kepemimpinan situasional kepala sekolah, para guru telah memahami tanggung jawabnya dalam memberikan yang terbaik terhadap anak didik sehingga kepuasan kerja tidak dapat memoderasi gaya kepemimpinan situasional terhadap kinerja guru. Sesuai dengan wanita di Bali dimana mereka bekerja keras dan sangat giat dalam bekerja untuk menambah perekonomian keluarga maka dari itu para guru taman kanak-kanak di Kota Singaraja semangat dan dedikasi nya sangat besar dalam melaksanakan tugas nya sebagai guru sehingga kinerja guru dapat meningkat tanpa harus memikirkan kepuasan kerja. Penelitian ini sesuai dengan hasil dari penelitian Arifzan (2015) gaya kepemimpinan tidak berpengaruh signifikan terhadap kinerja pegawai yang dimoderasi oleh kepuasan kerja.

Pengaruh Motivasi Kerja terhadap Kinerja Guru di Moderasi Kepuasan Kerja. Hasil dari penelitian ini adalah kepuasan kerja tidak memoderasi pengaruh motivasi kerja terhadap kinerja guru. Hal ini menunjukkan bahwa motivasi kerja adalah faktor penunjang kinerja guru dapat dilihat pada pengabdian guru taman kanak-kanak di Kota Singaraja dimana mereka dituntut untuk memiliki kesabaran, pengendalian emosi dalam mendidik anak usia dini sehingga dalam bekerja para guru tidak memikirkan rasa kepuasan kerja karena mereka sudah cukup termotivasi untuk selalu meningkatkan kinerjanya. Penelitian ini tidak sesuai dengan hasil dari penelitian Arifzan (2015) bahwa motivasi berpengaruh signifikan terhadap kinerja pegawai yang dimoderasi oleh kepuasan kerja.

\section{Kesimpulan}

Hasil penelitian ini membuktikan bahwa gaya kepemimpinan situasional, motivasi kerja, dan kepuasan kerja memiliki pengaruh secara langsung terhadap kinerja guru, dengan demikian peningkatan gaya kepemimpinan situasional dan motivasi kerja yang semakin baik maka akan meningkatkan kinerja guru ke arah yang lebih baik pula. Kepuasan kerja dalam penelitian ini terbukti tidak dapat memoderasi gaya kepemimpinan situasional dan motivasi kerja terhadap kinerja guru, artinya para guru TK di Kota Singaraja Bali memiliki semangat yang sangat besar dalam melaksanakan tugas nya sebagai guru dengan gaya kempemimpinan situasional dan motivasi kerja dari kepala sekolah sehingga dapat meningkatkan kinerja guru tanpa harus memikirkan rasa kepuasan kerja.

Keterbatasan penelitian ini terdapat pada saat melakukan penyebaran kuesioner kepada para guru yang mengajar di 33 Taman Kanak-Kanak di Kota Singaraja Bali yang telah ditentukan dan terdapat empat sekolah yang tidak memberikan izin untuk dilakukan penelitian dikarenakan di sekolah tersebut pada bulan Mei-Juni memiliki kegiatan yang padat dan juga bertepatan dengan perpisahan sekolah, sehingga mereka tidak berkenan untuk mengisi kuesioner.

Dari 146 kuesioner yang disebar ke taman kanak-kanak di Kota Singaraja Bali sesuai dengan jumlah yang telah ditentukan di masing-masing sekolah, namun pada saat pengembalian kuesioner, jumlah kuesioner berkurang karena tidak semuanya dikembalikan. Kuesioner yang kembali adalah 133 kuesioner, sehingga kegiatan analisis data digunakan dengan 133 kuesioner yang telah diterima.

Penelitian mengenai pengaruh gaya kepemimpinan situasional dan motivasi kerja terhadap kinerja guru dengan kepuasan kerja sebagai variabel moderasi sangat banyak dilakukan, serta hasil penelitiannya berbeda-beda. Ada yang menarik dari hasil penelitian ini yaitu gaya kepemimpinan situasional berpengaruh terhadap kinerja guru namun gaya 
kepemimpinan situasional tidak berpengaruh terhadap kinerja guru yang dimoderasi oleh kepuasan kerja.Sehingga bagi penelitian selanjutnya dapat dikaji lebih mendalam lagi alasan kepuasan kerja tidak berpengaruh sebagai moderasi antara gaya kepemimpinan situasional dan motivasi kerja terhadap kinerja guru.

\section{Daftar Pustaka}

Adeyemi, T. O. (2010). Principals' leadership styles and teachers' job performance in senior secondary schools in Ondo State, Nigeria. Journal of Education.

Arifzan. (2015). Pengaruh Gaya Kepemimpinan Dan Motivasi Kerja Terhadap Kinerja Dengan Kepuasan Kerja Sebagai Variabel Moderating Pada Pegawai Negeri Sipil Di Kantor Kesatuan Bangsa Politik Dan Perlindungan Masyarakat. Jurnal Program Pasca Sarjana Universitas Bung Hatta.

Diwiyani, D., \& Sarino, A. (2018). Gaya Kepemimpinan Situasional Kepala Sekolah Dan Motivasi Keja Guru Sebagai Determinan Kinerja Guru. Jurnal Manajerial. https://doi.org/10.17509/manajerial.v17i1.9763

Guterres, L. A., \& Supartha, W. G. (2016). Pengaruh Gaya Kepemimpinan dan Motivasi Kerja terhadap Kinerja Guru. Ekonomi Dan Bisnis Universitas Udayana.

Hamdani, Nila Kesumawati, Muhammad Kristiawan.(2018).The Influence of Teachers' Work Motivation and Principals' Managerial Competence on Teachers' Performance. Journal Of Humanities And Social Science.23(9):72-76

Husaini, A. (2017). Pengaruh Motivasi Kerja dan Kepemimpinan Situasional terhadap Kinerja Guru MTs Negeri di Kecamatan Gambut Kabupaten Banjar. Jurnal IImiah Ekonomi Bisnis.

Indriantoro, N., \& Supomo, B. (2016). Metodologi Penelitian Bisnis Untuk Akuntansi \& Manajemen. Yogyakarta : Penerbit BPFE.

Priansa, D. J. (2014). Perencanaan dan Pengembangan Sumber Daya Manusia. 200. https://doi.org/10.1039/c5cc07884a

Muhammad Basir.(2014).Pengaruh Kepuasan Kerja dan Motivasi Berprestasi Terhadap Kinerja Guru Pada SMP Negeri Kabupaten Wajo.Jurnal Panrita.9(3):442

Mulyasa, E. (2005). Menjadi guru profesional menciptakan pembelajaran kreatif dan menyenangkan. Bandung: Remaja Rosdakarya.

Pratiwi, S. D. (2013). Pengaruh motivasi kerja, kepuasan kerja, kepimpinan kepada sekolah menurut persepsi guru, dan iklim sekolah terhadap kinerja guru ekonomi SMP Negeri di Kabupaten Wonogiri. Jurnal Pendidikan Insan Mandiri.

Rachmawati, I. K. (2008). Manajemen Sumber Daya Manusia. Yogyakarta: Andi. 
Sutarno Suprayitno \&, R. D. S. (2016). Analisis Pengaruh Kepuasan Kerja terhadap Kinerja Guru dengan Kepemimpinan Kepala Sekolah sebagai Variabel Moderasi (Survei pada Guru PNS di SMP Negeri 1 Jumapolo). Jurnal Ekonomi Dan Kewirausahaan.

Uno, H. H. B. (2010). Model pembelajaran: menciptakan proses belajar mengajar yang kreatif dan efektif. Jakarta: Bumi Aksara. https://doi.org/10.1038/cddis.2011.1

Wahyudi.(2015). Kepemimpinan Kepala Sekolah dalam Organisasi Pembelajaran (Learning Organization).Bandung:Alfabeta. 